\title{
Histomorphological changes in gall bladder diseases and its association with helicobacter infection
}

\author{
K C Geetika ${ }^{1}$, Talwar $\mathrm{OP}^{2}$ \\ ${ }^{1}$ Department of Pathology, KIST Medical College, Lalitpur, Nepal \\ ${ }^{2}$ Department of Pathology, Manipal College of Medical Sciences, Pokhara, Nepal
}

\section{Keywords: \\ Adenocarcinoma; Giemsa stain; \\ Bile culture.}

\begin{abstract}
Background: Gall bladder diseases can be an incidental finding and when symptomatic, present with signs and symptom of cholecystitis and cholelithiasis. On histopathological examination however wide range of pathological changes are encountered including carcinoma. Several studies have been carried out to establish relationship of helicobacter infection with gallbladder diseases. This study tries to look at the frequency of risk factors, spectrum of histological changes and the relationship between different types of gallbladder diseases and helicobacter infection.
\end{abstract}

Materials and Methods: Total of 500 gallbladder specimen received over the period of 24 months was included in the study. Bile culture and histopathological examination cholecystectomy were performed with routine hematoxylin and eosin stain and Giemsa stain.

Result: Out of the 500 cases. Helicobacter was seen in 166(33\%) of cases. Carcinoma was seen in $7(1 \%)$ cases. Helcobacter infection was seen positive in 5/7 (71\%) malignant cases which showed a statistically significant $\mathrm{p}$ value of 0.03 .

Conclusion: Cholecystitis is the most common gallbladder disease. All gallbladder carcinomas were incidental finding and were of lower grade and stage. Helicobacter infection was prevalent in variety of gallbladder pathology and had significant association with gallbladder carcinoma. However, definite relation between the helicobacter infection and gallbladder diseases cannot be concluded.

\section{INTRODUCTION}

The histopathological entities encountered in gallbladder ranges from cholelithiasis on one end of the spectrum and carcinoma on another. Cholelithiasis accounts of more than $95 \%$ of all biliary tract diseases. ${ }^{1}$ It has an incidence of $11 \%$ in United States according to Framingham study ${ }^{2}$ and is four times more common in women than in men with peak age

\section{Correspondence:}

Dr. Geetika K.C., MD

Department of Pathology,

KIST Medical College, Imadole, Lalitpur

Email Address: geetikakc@hotmail.com group of sixth and seventh decade of life. ${ }^{3}$ Majority of them are asymptomatic as depicted by its incidence of $19.5 \%$ in one of the study done on autopsy cases in $1960 .{ }^{4}$ Acute calculous cholecystitis is nearly always due to impaction of stone in the cystic duct. ${ }^{5,6}$

Bile infection is seen in $50 \%$ of cholecystitis cases and is thought to be a secondary phenomenon. ${ }^{7}$ Aerobes such as E. coli, Enterobacter, Enterococcus, Klebsiella predominate over anaerobes such as Clostridium, Peptostreptococcus, Bacteroides and several other microbes have been isolated. ${ }^{8}$ Added to the list is bile resistant Helicobacter species that 
have been reported in the gallbladder mucosa in various studies. ${ }^{9,10}$

Apart from cholecystitis and cholelithiasis other histopathological changes such as congenital anomalies, cholesterolosis, hydrops and mucocele, follicular cholecystitis, eosinophilic cholecystitis, xanthogranulomatous cholecystitis, ischemia and infraction may be seen. Also seen are non-neoplastic epithelial alterations, non-neoplastic tumour like lesions, noninvasive epithelial lesion and carcinoma. ${ }^{1}$ All of these are usually incidental finding, including carcinoma. ${ }^{11}$

As mentioned earlier, Helicobacter species are seen in association with gallbladder diseases. Since the discovery of helicobacter pylori in 1984, by Marshal and Warren more than 30 different species of helicobacter have now been discovered. ${ }^{12}$ Several studies have been carried out seeking similar results regarding gallbladder diseases and helicobacter species. ${ }^{13-15}$ The aim of this study was to to study the frequency of risk factors associated with cholecystitis, the histomorphological spectrum of gallbladder diseases and attempted to find out its association with Helicobacter infection.

\begin{tabular}{|c|c|c|c|}
\hline $\begin{array}{l}\text { HISTOPATHOLOGICAL } \\
\text { DIAGNOSIS }\end{array}$ & $\begin{array}{c}\text { Helicobacter } \\
\text { positive }\end{array}$ & $\begin{array}{l}\text { Helic obacter } \\
\text { negative }\end{array}$ & Total \\
\hline Chronic cholecystitis & $117(23 \%)$ & $239(48.2 \%)$ & $356(71.2 \%)$ \\
\hline $\begin{array}{l}\text { Chronic cholecystitis with } \\
\text { cholesterolosis }\end{array}$ & $32(6 \%)$ & $55(11 \%)$ & $87(17 \%)$ \\
\hline $\begin{array}{l}\text { Chronic cholecystis with } \\
\text { cholesterolosis and polyp }\end{array}$ & $0(0 \%)$ & $1(0.2 \%)$ & $1(0.2 \%)$ \\
\hline $\begin{array}{l}\text { Chronic cholecystitis with } \\
\text { intestinal metaplasia }\end{array}$ & $3(1 \%)$ & $7(1 \%)$ & $10(2 \%)$ \\
\hline $\begin{array}{l}\text { Chronic cholecystitis with } \\
\text { dystrophic calcification }\end{array}$ & $0(0 \%)$ & $3(1 \%)$ & $3(1 \%)$ \\
\hline $\begin{array}{l}\text { Chronic cholecystitis with } \\
\text { cholesterolosis with dystro- } \\
\text { phic calcification }\end{array}$ & $0(0 \%)$ & $1(0.2 \%)$ & $1(0.2 \%)$ \\
\hline $\begin{array}{l}\text { Chronic cholecystitis with } \\
\text { cholesterolosis and intestinal } \\
\text { metaplasia }\end{array}$ & $0(0 \%)$ & $2(0.4 \%)$ & $2(0.4 \%)$ \\
\hline $\begin{array}{l}\text { Chronic cholecystitis with } \\
\text { foreign body reaction }\end{array}$ & $0(0 \%)$ & $1(0.2 \%)$ & $1(0.2 \%)$ \\
\hline $\begin{array}{l}\text { Chronic cholecystitis with } \\
\text { pyloric metaplasia and mild } \\
\text { dysplasia }\end{array}$ & $0(0 \%)$ & $1(0.2 \%)$ & $1(0.2 \%)$ \\
\hline $\begin{array}{l}\text { Chronic cholecystitis with } \\
\text { moderate dysplasia }\end{array}$ & $0(0 \%)$ & $2(0.4 \%)$ & $2(0.4 \%)$ \\
\hline Acute on chronic cholecystitis & $3(1 \%)$ & $10(2 \%)$ & $13(3 \%)$ \\
\hline Empyema gallbladder & $0(0 \%)$ & $4(1 \%)$ & $4(1 \%)$ \\
\hline Follicular cholecystitis & $1(0.2 \%)$ & $2(0.4 \%)$ & $3(1 \%)$ \\
\hline Eosinophilic cholecystitis & $3(1 \%)$ & $2(0.4 \%)$ & $5(1 \%)$ \\
\hline \multirow{2}{*}{$\begin{array}{ll}\text { Adenoma } & \text { without dysplasia } \\
& \text { with dysplasia }\end{array}$} & $1(0.2 \%)$ & $2(0.4 \%)$ & $3(1 \%)$ \\
\hline & $1(0.2 \%)$ & $0(0 \%)$ & $1(0.2 \%)$ \\
\hline Carcinoma & $5(1 \%)$ & $2(0.4 \%)$ & $7(1 \%)$ \\
\hline Total & $166(33 \%)$ & $334(67 \%)$ & $500(100 \%)$ \\
\hline
\end{tabular}

\section{MATERIAL AND METHODS}

This was a prospective study, conducted in department of pathology, Manipal Teaching Hospital, Pokhara, Nepal over the period of 24 months from October 2010 to October 2012. All the cases of cholecystectomy were included in the study. Informed written consent was obtained from all patients. Bile was aspirated peroperatively in a $5 \mathrm{ml}$ syringe and microbiological culture done. The bile was then inoculated in blood agar and chocolate agar at $37^{\circ} \mathrm{C}$ for 72 hours along with Brucella agar with campylobacter supplement II (Butzler) was used for culture in microaerophilic environment. The cholecystectomy specimens fixed in $10 \%$ formalin was sent to department of pathology where it was processed routinely. The slides were examined microscopically after Hematoxylin and Eosin staining and Giemsa staining. Data were analyzed using SPSS.

\section{RESULTS}

A total of 500 cholecystectomy specimens were received in the study period. There were total of $390(78 \%)$ female and $110(22 \%)$ male with male to female ratio of $1: 3.5$. The peak age group involved by gall bladder diseases was 30 to 40 years followed by $40-50$ years with the mean age was 44 years.

\section{BILE CULTURE FINDINGS}

Out of 500 cholecystectomy cases; 247 cases had bile available for culture. Among 247 cases, 82 cases (35\%) were positive. E. coli was seen in $36(15 \%)$ followed by Enterococcus $13(5 \%)$, Actenobacter $11(5 \%)$ and Klebsiela $11(4 \%)$. In few cases Streptococcus $(n=8 ; 3 \%)$ and Pseudomonas $(\mathrm{n}=7 ; 3 \%)$. There was no growth in 161 $(65 \%)$ of the cases. Growth of Helicobacter bacilli under microareophilic condition was not detected in any of the available cases.

\section{HISTOPATHOLOGICAL FINIDNGS}

Microscopically, cholesterolosis was seen in $92(18 \%)$ of the case. Metaplasia was seen in14 (3\%) of cases and intestinal type was more $(\mathrm{n}=13 ; 2 \%)$ compared to $1(0.2 \%)$ of pyloric metaplasia. Reactive atypia was noted in $36(7 \%)$ of the cases. Dysplasia was seen in $6(1 \%)$ of cases. Polyp was seen in $1(0.2 \%)$ of the cases, adenoma in $5(1 \%)$ and malignancy in $7(1 \%)$ of cases.

Helicobacter pylori was seen in $166(33 \%)$ of cases. There was no statistical significance between any of these microscopic findings and Helicobacter infection except for malignancy which has a significant $\mathrm{p}$ value of $0.03(<0.05)$.

Chronic cholecystitis accounted for the largest number of cases $(\mathrm{n}=355 ; 71 \%)$ followed by chronic cholecystitis with cholesterolosis (fig 1 and fig 2 ) in ( $\mathrm{n}=87 ; 17 \%)$ of cases. 


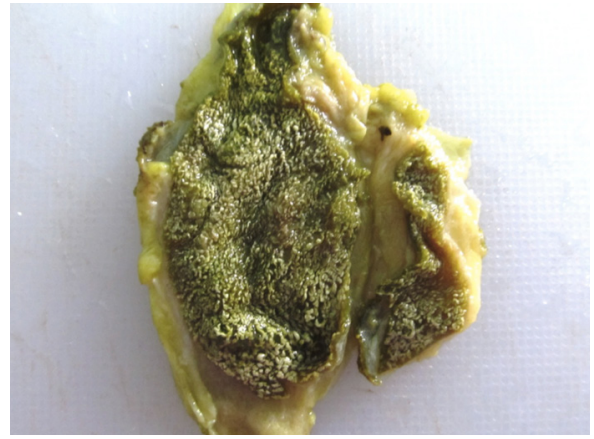

Figure 1: Gross of cholesterolosis with yellow streaks of cholesterol deposition.

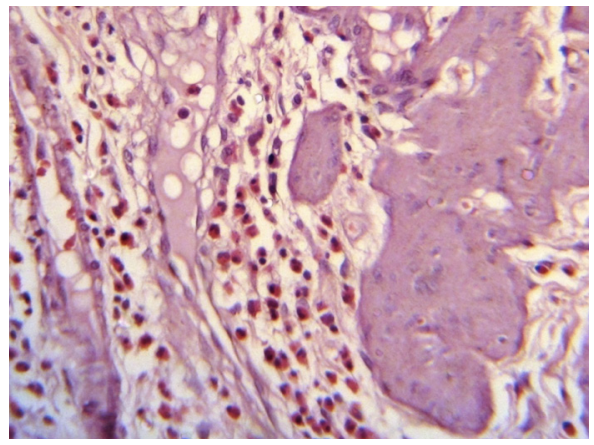

Figure 3: Eosinophilic cholesytitis with sheets of eosinophilic infiltration, $H \& E$. (400X).

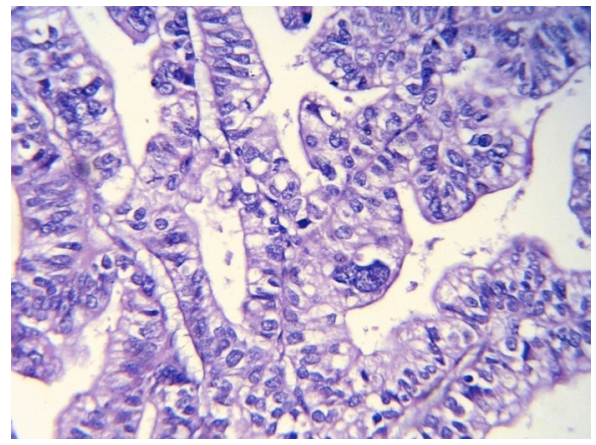

Figure 5: Gallbladder carcinoma with marked nuclear pleomorphism, $H \& E$. (400X).

Eosinophilic cholecystitis was seen in $5(1 \%)$ of the cases (fig.3). Detail histological findings are shown in Table 1.

Gall bladder carcinoma (fig. 4 to 6) was seen in age group ranging from 36 to 67 years with the mean age being 55 years. Male to female ratio was $1: 1.3$. Clinically gall bladder carcinoma was daignosied as cholelithiasis $(n=4 ; 58 \%)$, chronic cholecystitis $(n=2 ; 28 \%)$ and acute cholecystitis $(n=1 ; 14 \%)$. Five $(71 \%)$ out of seven cases were seen reaching up to muscularis propria and were staged as T1bNxMx while $2(28 \%)$ cases were of T2NxMx. Helicobacter sp. was seen in $5(71 \%)$ cases. Helicobacter infection and malignancy showed a significant statistical relationship with a $\mathrm{p}$ value of 0.03 and Odds ratio of 5.15 (95\%CI: 0.98-26.86).

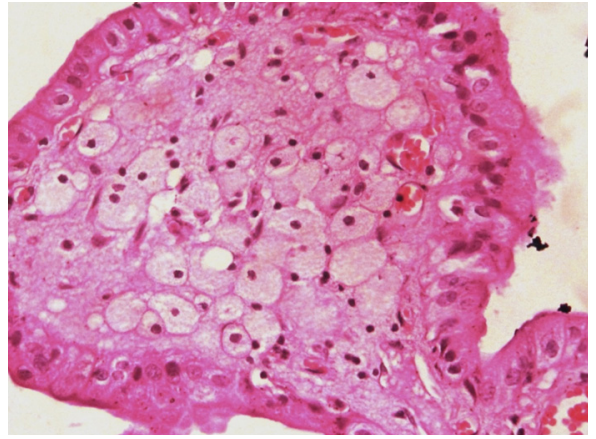

Figure 2: Cholesterelosis with numerous foamy macrophages in the lamina propria, $H \& E$. (400X).

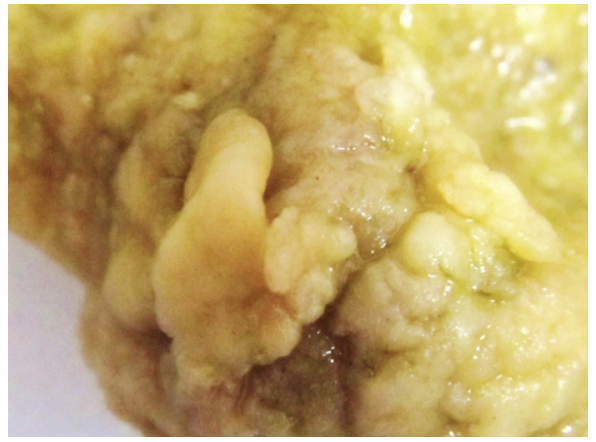

Figure 4: Gross of gallbladder carcinoma with prominent nodule.

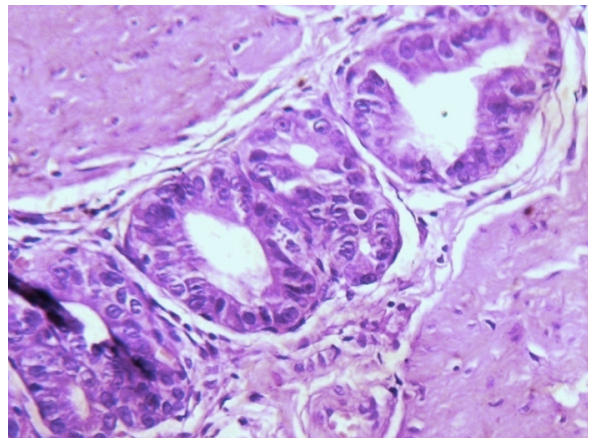

Figure 6: Infiltration of gallbladder wall with malignant cells in glandular pattern, $H \& E$. (400X)

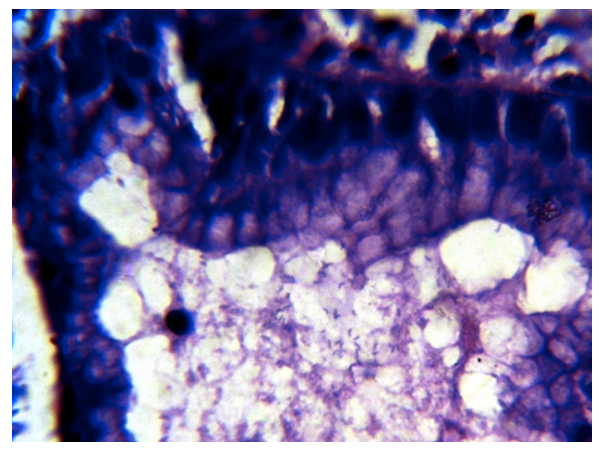

Figure 7: Helicobacter species in the gallbladder lining on $H \& E$. (1000X). 


\section{DISCUSSION}

Gallbladder diseases are four times more common in female than male and are found to increase in frequency with age. ${ }^{3}$ By $6^{\text {th }}$ decade of life every $4^{\text {th }}$ women is found to be affected by gallbladder disease. ${ }^{3}$ The present study showed a female predominance accounting to $390(78 \%)$ of cases with male to female ratio of 1:3.5. The peak age group among both male and female affected by gallbladder disease in general was $30-40$ years. The age range was from 10 to 94 years. Similar finding were observed in other studies. ${ }^{16,17}$

Many organisms have been isolated worldwide in bile. The route of infection are ascending and descending infections. The organisms isolated are Escherichia coli, Streptococci, Klebsiella species, Enterobacter species, Proteus species, Citrobacter species, Staphylococcus species, Pseudomonas, Salmonella typhi, Clostridium perfringes, Bacteroides fragilis and others. In our study all of the organisms isolated were aerobic bacteria. E. coli was the most common organism found in $36(15 \%)$ cases. According to the order of frequency, Enterococcus 13 (5\%), Actenobacter 11 (5\%) and Klebsiela $11(4 \%)$ were other organisms isolated. Also seen were few cases of Streptococcus $8(3 \%)$ and Pseudomonas 7 (3\%). In the study done by Brook et $\mathrm{al}^{18} 48 \%$ of the species were aerobic bacteria, $3 \%$ anaerobic bacteria and $49 \%$ were mixed. E. coli was the most common organism isolated, followed by Klebsiela.

No helicobacter colonies were grown under microaerophilic condition in a Brucella agar with Campylobacter supplement, in any of our cases. Similar findings were observed in a studty done Roe et al ${ }^{19}$ and Bohr et al. ${ }^{19}$ However Mishra et $\mathrm{al}^{20}$ in their study found $13(44.4 \%)$ positive cases and 11 $(55.6 \%)$ negative cases for Helicobacter pylori culture. The lack of growth in our study could be because of coexistence of other aerobic organisms along with various other factors. Chronic cholecystitis with dystrophic calcification was seen in $3(1 \%)$ of the cases and along with cholesterolosis in $1(0.2 \%)$ of the cases. In a study done in Massachusetts General Hospital, ${ }^{21} 0.16 \%$ of cholecystectomy cases were calcified gallbladder, which was similar to our study finding. No dysplasia or malignancy was noted along with calcified gallbladder.

In our study reactive atypia was noted in $36(7 \%)$ of the cases. In the study done by Bracia22 regenerative/reactive changes were seen in $73 \%$ of cases which was very much higher than our finding. In the present study, metaplasia was seen in $14(3 \%)$ of cases and intestinal type was more 13 ( $2 \%$ ) compared to $1(0.2 \%)$ of pyloric metaplasia. Pradhan et al, ${ }^{23}$ found intestinal metaplasia in $20(5.26 \%)$ of cases which was more than our study. Polyp was seen in $2(0.4 \%)$ of our study cases.

Dysplasia was seen in $6(1 \%)$ cases. It was graded into mild, moderate and severe and each group had $2(0.4 \%)$ cases each. In the study of Mittal et al, ${ }^{24}$ dysplasia was seen in 1
$(0.08 \%)$ of cases. Pradhan et $\mathrm{al}^{23}$ however found dysplasia in $15(3.95 \%)$ of cases which was higher than our study finding. Adenoma was seen in $5(1 \%)$ of cases in our study. It was seen in $10(0.8 \%)$ cases in combination with metaplasia in study done by Mittal et al. ${ }^{24}$ Gall bladder carcinoma was seen in $7(1 \%)$ of cases in current study with a significant $p$ value of 0.03 when correlated with helicobacter infection. Pradhan et $\mathrm{al}^{23}$ had $10(2.63 \%)$ cases and Parajuli et $\mathrm{al}^{25}$ had $7(2.5 \%)$ cases of malignancy.

Helicobacter species have long been identified in gallbladder and biliary tract. However, its definite role and relation in the gallbladder diseases have not been well defined. In the meta-analysis published by Zhou et $\mathrm{al}^{26}$ in 2011, showed that the Helicobacter detection rate in gallbladder to range from $3.02 \%$ to $80 \%$. The detection rate varied with the type of methods used. In our study, Helicobacter was positive in $166(33 \%)$ of cases and negative in 334 (67\%) of cases. Parajuli et $\mathrm{al}^{25}$ found 50 (19\%) of their cases to be positive for Helicobacter infection in H\&E and WSS. Variable findings were observed in other studies. ${ }^{20,27,28}$

In all the categories we had helicobacter negative cases more than positive. However helicobacter prevalence was more in eosinophilic cholecystitis and carcinoma cases. Acute cholecystitis had $3(1 \%)$ and chronic cholecystitis had $117(23 \%)$ prevalence of helicobacter infection. Karagin PH et $\mathrm{al}^{16}$ saw in their study that 4 out of $50(8 \%)$ were acute cholecystitis with helicobacter infection (higher than our study) and 3 out of $50(6 \%)$ cases of chronic cholecystitis had helicobacter infection (lower than our study). All the carcinomas detected in our studies were incidental findings. The rate of incidental carcinoma ranges from $0.14 \%$ to $6.1 \%$ worldwide. ${ }^{29}$ According to the WHO 2008 data gallbladder carcinoma incidence was $1.7 \%$ in South East Asia. ${ }^{30}$ It was seen in $1.3 \%$ of male and $2 \%$ females. ${ }^{30}$

Helicobacter infection has been reported in various articles in association with gallbladder carcinoma. In the present study, Helicobacter was seen in $5(72 \%)$ out of 7 malignant cases. Both the higher stage (T2) tumours were positive for Helicobacter. The $\mathrm{p}$ value obtained between helicobacter infection and gallbladder carcinoma was 0.03 which was significant and odds ratio of 5.15 (95\% CI of $0.98-26.86)$. In other studies over the world various helicobacter species were specifically identified with relative risk of gallbladder carcinoma ranging from 2.6 to $9.9 \%$ and $95 \%$ CI of 0.6 to 70.5. ${ }^{20,25,27}$

\section{CONCLUSION}

Chronic cholecystitis was the most common histopathological diagnosis encountered. Helicobacter infection was prevalent in variety of gallbladder pathology and had significant association with gallbladder carcinoma. However, definite relation between the helicobacter infection and gallbladder diseases cannot be concluded 


\section{REFERENCES}

1. Crawford JM, Liu C. Liver and biliary tract. In: Kumar V, Abbas AK, Fausto N, Aster JC, (eds). Robbins and Cotran pathologic basis of disease. 8th ed. Saunders Elsevier: Philadelphia; 2010. pp 882-90. Crossref

2. Friedman GD, Kannel WF, Dawber TR. The epidemiology of gallbladder diseases. Observations in the Framingham study. J Chronic Dis 1966;19:273-92. Crossref

3. Rosai J. Rosai and Ackerman's surgical pathology. Vol 19th ed. Mosby: Missouri; 2004.1393pp.

4. Torvik A, Höivik B. Gallstones in an autopsy series. Acta Chir Scand 1960;120:168-74. PMid:13777615

5. Glenn F. Acute cholecystitis. Surg Gyanecol Obstet 1976;143:56-60. PMid:936049

6. Hallendorf LC, Dockerty MB, Waugh JM. Gangrenous cholecystitis. A clinical and pathological study of 100 cases. SurgClin North Am 1948;28:979-98. PMid:18878461

7. Csendes A, Burdiles P, Maluenda F, Diaz JC, Csendes P, Mitru N. Simultaneous bacteriologic assessment of bile from gallbladder and common bile duct in control subjects and patients with gallstones and common duct stones. Arch Surg 1996;131:389-94. Crossref

8. Adsay VN. Gallbladder, extrahepatic biliary tree, and ampulla. In: Mills SE editor. Sternberg's diagnostic surgical pathology. 5th ed. Lippincott Williams and Wikins: Philadelphia; 2010. Pp160151.

9. Kawaguchi M, Saito T, Ohno $\mathrm{H}$ et al. Bacteria closely resembling Helicobacter pylori detected immunohistologically and genetically in resected gallbladder mucosa. J Gastroenterol 1996;31:294-8. Crossref

10. Blaser MJ. Helicobacters and biliary tract disease. Gastroenterology 1998;114:840-5. Crossref

11. Shrestha HG, Bajracharya M. Incidence of cholelithiasis and its correlation with cancer of gallbladder at TU Teaching Hospital. JNMA J Nepal Med Assoc 1991;29:264-7.

12. Marshal BJ, Warren JR. Unidentified curved bacilli in the stomach of patients with gastritis and peptic ulceration. Lancet 1984;1:1311-5. Crossref

13. Fox JG, Dewhirst FE, Shen $Z$ et al. Hepatic Helicobacter species identified in bile and gallbladder tissue from Chileans with chronic cholecystitis. Gastroenterology 1998;114: 755-63. Crossref

14. Leong RW, Sung JJ. Review article: Helicobacter species and hepatobilliary disease. Aliment Pharmacol Ther 2002;16:1037-45. Crossref
15. Fukuda K, Kuroki T, Tajima $\mathrm{Y}$ et al. Comparative analysis of Helicobacter DNAs and biliary pathology in patients with and without hepatobiliary cancer. Carcinogenesis 2002;23:1927-31. Crossref

16. Karagin PH, Stenram U, Wadstrom T, Ljungh A. Helicobacter species and common gut bacterial DNA in gallbladder with cholecystitis. World J Gastroenterol 2010;6:4817-22. Crossref

17. Moricz A, Melo M, Castro AM, Campos T, Silva RA, Pacheco AM Jr. Prevalence of Helicobacter spp in chronic cholecystitis and correlation with changes on the histological pattern of the gallbladder. Acta Cir Bras 2010;25:218-24. Crossref

18. Brook I. Aerobic and anaerobic microbiology of biliary tract infection. J Clin Microbiol 1989;27:2373-5. PMid:2584384

19. Martel C de, Plummer M, Parsonnet J, Doorn LJ, Franceschi S. Helicobacter species in cancer of the gallbladder and extrahepatic biliary tract. Br J Cancer 2009;100:194-9. Crossref

20. Mishra RR, Tewari M, Shukla H. Helicobacter pylori and pathogenesis of gallbladder cancer. J Gastroenterol Hepatol 2011;26:260-6. Crossref

21. Stephen AE, Berger DL. Carcinoma in the porcelain gallbladder: a relationship revisited. Surgery 2001;129:699-703. Crossref

22. Barcia JJ. Histologic analysis of chronic inflammatory patterns in the gallbladder: diagnostic criteria for reporting cholecystitis. Ann Diagn Pathol 2003;7:147-53 Crossref

23. Pradhan SB, Dali S. Relation between gallbladder neoplasm and helicobacter hepaticus infection. Kathmandu Univ Med J 2004;2:3315. PMID: 16388245

24. Mittal P, Jesudason MR, Nayak S. Selective histopathology in cholecystectomy for gallstone disease. Indian J Gastroenterol 2010;29:32-6. Crossref

25. Parajuli S, Koirala U. Incidence of Helicobacter hepaticus and its relation to gallbladder carcinoma. Journal of Pathology of Nepal 2011;1:122-5. Crossref

26. Zhou D, Zhang Y, Gong W et al. Are Helicobacter pylori and other Helicobacter species infection associated with human biliary lithiasis? A meta-analysis. PLoS ONE 2011[cited 2012 Nov 3];6(11):e27390. Available from Crossref

27. Pradhan SB. Study of Helicobacter hepaticus in gallbladders with cholelithiasis and its sensitivity pattern. Kathmandu Univ Med J 2009;7:125-8. PMID:20071844

28. Pandey M. Helicobacter species are associated with possible increase in risk of biliary lithiasis and benign biliary diseases. World J Surg Oncol 2007;5:94. Crossref 
29. Goldin RD, Roa JC. Gallbladder cancer: A morphological and molecular update. Histopathology 2009;55:218-29. Crossref

30. International agency for research on cancer WHO. Globocan 2008 estimated cancer incidence, mortality, prevalence and disabilityadjusted life years (DALYs) worldwide. [Online]. 2008 [cited 2012 Oct 30];[1 screen]. Available from Crossref 